\title{
Appearance of Maxima on Conductometric Titration Curves of Sulfonic Acids and the Evidence of Strong Homoconjugation Reactions in Benzonitrile
}

\author{
Masashi HoJO ${ }^{\dagger}$ and Zhidong CHEN \\ Department of Chemistry, Faculty of Science, Kochi University, Akebono-cho, Kochi 780-8520, Japan
}

Keywords Conductometric titration, homoconjugation, sulfonic acids, benzonitrile, association

The conductometric titrations of acids with bases usually give decreasing or increasing straight lines from the beginning to the equivalence point in protic solvents. However, in aprotic solvents, such as acetone ${ }^{1}$ and acetonitrile ${ }^{2}$, maxima at the half equivalence point on titration curves have been observed for carboxylic acids with amine bases. The cause of the maxima at the half equivalence point has been attributed to homoconjugation reactions ${ }^{2}$ between an acid (HA) and the conjugate base anion $\left(\mathrm{A}^{-}\right)$on the neutralization: $\mathrm{B}+2 \mathrm{HA} \rightleftharpoons \mathrm{BH}^{+} \ldots \mathrm{H}_{2} \mathrm{~A}^{-}$. In a poorly solvating solvent, nitrobenzene, the maxima could be observed even at the one-third, and not at the half equivalence point, suggesting the formation of an $\mathrm{A}^{-}(\mathrm{HA})_{2}$-type homoconjugate species. ${ }^{3}$ We have reported maxima on conductometric titration curves of phosphoric, phosphonic, and related organophosphorus acids with triethylamine in DMF. ${ }^{4}$ The stability of the homoconjugated species was found to depend much upon the number of $\mathrm{OH}$ groups involved homoconjugation reactions, e.g., not $(\mathrm{PhO})_{2} \mathrm{PO}(\mathrm{OH})$ but $\mathrm{PhOPO}(\mathrm{OH})_{2}$ gave a maximum in $\mathrm{DMF}$, regardless of the acidities of the acids.

Gunduz et $a l .{ }^{5}$ stressed an important role of the base strength of a conjugate anion upon the appearance of maxima in conductometric titrations of substitutedacetic and benzoic acids. In acetonitrile, the equilibrium constants of the homoconjugation reactions of acetate and benzoate ions with two acid moleclues $\left(\mathrm{A}^{-}+2 \mathrm{HA} \rightleftharpoons \mathrm{A}^{-}(\mathrm{HA})_{2}, K_{\text {homo }}\right)$ have been determined to be $5.7 \times 10^{7}$ and $\mathrm{ca} .1 \times 10^{7}$, respectively. ${ }^{6}$ Some phenols, especially 3,5-dinitrophenol etc. ${ }^{1,7}$ can form the homoconjugate species in aprotic solvents. The homoconjugation reaction or the appearance of a maximum on conductometric curve of sulfuric acid $\left(\mathrm{SO}_{2}(\mathrm{OH})_{2}\right)$ has been observed in acetonitrile ${ }^{2,8}$ and acetone. ${ }^{9}$ However, maxima on conductometric curves for sulfonic acids $\left(\mathrm{RSO}_{2}(\mathrm{OH})\right)$ have not been reported so far, even though fairly large homoconjugation constants of sulfonic

† To whom correspondence should be addressed.

Z. C. present address: Department of Applied Chemistry and Chemical Engineering, Faculty of Engineering, Yamaguchi University, Ube, Yamaguchi 755-8611, Japan. acids were obtained in acetonitrile. ${ }^{10}$ An sulfonic acid has only a single $\mathrm{OH}$ group, while sulfuric acid has two $\mathrm{OH}$ groups in the molecule. Therefore, the stability of the homoconjugated species from an sulfonic acid must have been too small to give a maximum on the titration curve; this point encouraged us to perform the present study.

Sulfonic acids are rather strong acids (e.g., $\mathrm{p} K_{\mathrm{a}}=0.7$ for benzenesulfonic acid) ${ }^{11}$ in aqueous solution, however, the acidities of the acids are extremely weakened in aporic solvents. ${ }^{10,12}$ The dissociation and homoconjugation constants of methanesulfonic and related acids have been determined in propylene carbonate, and compared with those in acetonitrile. ${ }^{13}$ We have report$\mathrm{ed}^{14}$ on the formation constants of "triple ions" of trialkylammonium sulfonates and nitrate through hydrogen bonding forces as well as Coulombic forces in benzonitrile. Judging from the 1:1 association and "triple ion" formation constants of $\mathrm{R}_{3} \mathrm{NH}^{+} \mathrm{A}^{-}$in benzonitrile, the basicity of the conjugate anions were found to increase as follows: $\mathrm{NO}_{3}{ }^{-}<\mathrm{PhSO}_{3}{ }^{-}<p-\mathrm{TsO}^{-}<\mathrm{CH}_{3} \mathrm{SO}_{3}{ }^{-}$.

In the present study, conductometric titrations of sulfonic acids with amine and related bases are attempted in order to verify the fairly strong basicity of sulfonate ions in benzonitrile (relative permittivity: $\varepsilon_{\mathrm{r}}=25.2$ ) ${ }^{15}$ the acid-base and self-association reactions in the solutions are discussed. The small solvation abilitiy of benzonitrile (Gutmann's donor and acceptor numbers: ${ }^{16}$ 11.9 and 15.5 , respectively) should affect the reactions in the solvent.

\section{Experimental}

Commercially obtained benzonitrile (Wako, GR grade) was found to be sufficient for the present work, and was used as received. Acetonitrile (Wako, GR grade) was dried over $\mathrm{CaH}_{2}$ for several days, and the supernatant was distilled from newly added $\mathrm{CaH}_{2}$. Methanesulfonic (Wako, GR grade $>98 \%$ ) and trifluoromethanesulfonic (Wako or TCI, GR grade $>98 \%$ ) acids were used as received. $p$-Toluenesulfonic acid monohydrate (Wako, GR grade) and benzenesulfonic acid 
monohydrate (TCI, EP grade) were dried in vacuo over $\mathrm{P}_{2} \mathrm{O}_{5}$ at $70-80^{\circ} \mathrm{C}$ for several days. Commercially obtained bases, e.g., triethylamine (Wako, GR grade $>99 \%$ ) and tributylamine (Wako, GR grade), were used as received. The preparation methods of tetraethylammonium trifluoromethanesulfonate and perchlorate were mentioned previously. ${ }^{17}$

Conductances were measured with a Yanagimoto conductivity outfit (Model MY-8) or a Hewlett-Packard LCR meter (Model 4263A) at $1 \mathrm{kHz}$ in a Yanagimoto conductivity cell (Type A: a cell constant of 0.5142 ) at $25 \pm 0.02^{\circ} \mathrm{C}$. A $25 \mathrm{ml}$ acid solution was titrated with a hundred-fold concentration of an amine base under nitrogen atmosphere. For obtaining association constants in the presence of higher aggregates, the conductivities of acids or salts were analyzed using our method. ${ }^{4,14,18}$

\section{Results and Discussion}

Figure 1 shows the conductometric titration curves of $p$-toluenesulfonic acid ( $p$-TsOH, $25 \mathrm{ml}$ ) of various concentrations with triethylamine $\left(\mathrm{Et}_{3} \mathrm{~N}\right)$ of the hundredfold concentrations in benzonitrile $(\mathrm{PhCN})$ at $25^{\circ} \mathrm{C}$. When the concentration of $p$-TsOH was low $\left(\leq 2 \times 10^{-3}\right.$ mol $\mathrm{dm}^{-3}$ ), the conductance increased almost linearly with increasing amount of $\mathrm{Et}_{3} \mathrm{~N}$ up to the equivalence point $(250 \mu \mathrm{l})$. However, when the concentration of $p$ TsOH was $5.0 \times 10^{-3} \mathrm{~mol} \mathrm{dm}^{-3}$, the titration curve gave a maximum at one-third $(80-85 \mu \mathrm{l})$ of the equivalence point. For $1.0 \times 10^{-2} \mathrm{~mol} \mathrm{dm}^{-3} p$-TsOH, the maximum in the titration curve was prolonged and the maximum

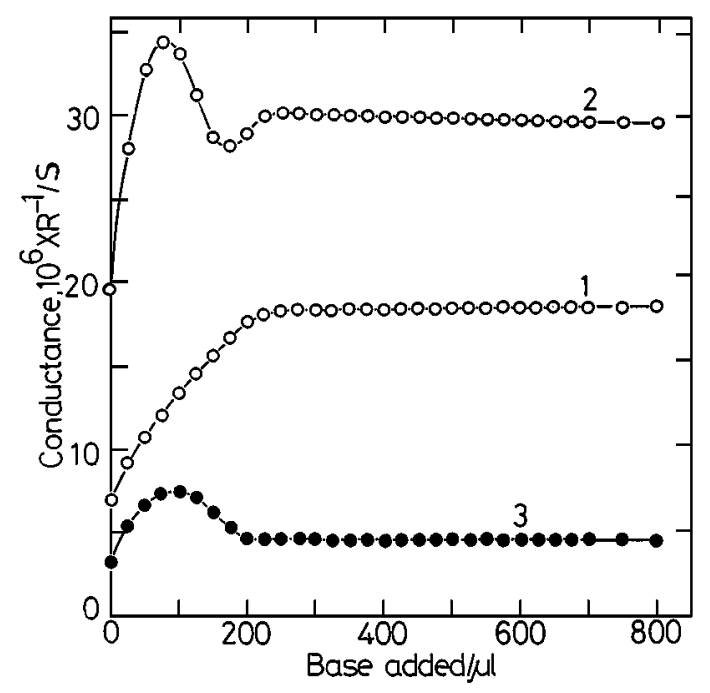

Fig. 1 Conductometric titration curves of $p$-toluenesulfonic acid ( $25 \mathrm{ml}$ solutions) with triethylamine in benzonitrile at $25^{\circ} \mathrm{C}$. The concentrations of the acid and the added base are (1) 0.0020 and 0.20 , (2) 0.0050 and 0.50 , (3) 0.010 and 1.0 mol dm ${ }^{-3}$. The conductance unit is $10^{5} \times R^{-1} / \mathrm{S}$ for (3), where $R$ is electrolytic resistance. point was somewhat delayed. The titration of $p-\mathrm{TsOH}$ with tributylamine $\left(n-\mathrm{Bu}_{3} \mathrm{~N}\right)$ in benzonitrile gave results similar to those with $\mathrm{Et}_{3} \mathrm{~N}$, except that each conductance value with $n-\mathrm{Bu}_{3} \mathrm{~N}$ was lower by a factor of ca. 0.85 than the corresponding value with $\mathrm{Et}_{3} \mathrm{~N}$ because of larger size of the base. Titration of $p-\mathrm{TsOH}$ with a strong base, 1,1,3,3-tetramethylguanidine, caused changes in conductance with time during titration, probably because of some reaction between the strong base and the solvent. The conductance of the strong base- $\mathrm{PhCN}$ solution itself changed substantially by aging, whereas it was not observed in the strong base-MeCN solution. Muney and Coetzee ${ }^{19}$ observed minor changes in the conductances of 1,3-diphenylguanidine-MeCN solutions, attributing it to deprotonation from the solvent.

The appearance of the maximum at the one-third equivalence point suggested that a homoconjugation reaction occurred between the conjugate anion $\left(\mathrm{A}^{-}\right)$and two acid molecules (HA) on the neutralization with the amine (B) in benzonitrile:

$$
\mathrm{B}+3 \mathrm{HA} \rightleftharpoons \mathrm{BH}^{+} \ldots \mathrm{A}^{-}(\mathrm{HA})_{2}
$$

The structure of the homoconjugation species, $\mathrm{A}^{-}(\mathrm{HA})_{2}$, is illustrated in Scheme 1. At the equivalence point $(250 \mu \mathrm{l})$, the acid-base reaction of 1:1 must occur (Eq. (2)); however, the produced salt $\left(\mathrm{BH}^{+} \mathrm{A}^{-}\right)$may form partly "triple ions" through the interaction of hydrogen bonding forces as well as Coulombic forces, as shown by Eq. (3).

$\mathrm{B}+\mathrm{HA} \rightleftharpoons \mathrm{BH}^{+} \mathrm{A}^{-}$

$\mathrm{BH}^{+} \mathrm{A}^{-} \rightleftharpoons 1 / 3\left(\mathrm{BH}^{+}\right)_{2} \mathrm{~A}^{-}+1 / 3 \mathrm{BH}^{+}\left(\mathrm{A}^{-}\right)_{2}$

We have reported the formation constants of "triple ions" from tributylammonium $p$-toluenesulfonate and other sulfonates in aprotic solvents with higher permittivities. ${ }^{14}$ In acetonitrile, $1.0 \times 10^{-2} \mathrm{~mol} \mathrm{dm}^{-3} p-\mathrm{TsOH}$ solutions gave only a very small maximum after the half-equivalence point by the addition of $1.0 \mathrm{~mol} \mathrm{dm}^{-3}$ $\mathrm{Et}_{3} \mathrm{~N}$ solution.

Another sulfonic acid, benzenesulfonic acid $\left(\mathrm{PhSO}_{3} \mathrm{H}\right)$ in benzonitrile gave conductometric titration curves similar to those of $p$ - $\mathrm{TsOH}$; however, methanesulfonic acid $\left(\mathrm{CH}_{3} \mathrm{SO}_{3} \mathrm{H}\right)$ gave a larger maximum at the same point, as shown in Fig. 2. The strength in acidities of the sulfonic acids may explain the order in conductances after the equivalence point: $\mathrm{CH}_{3} \mathrm{SO}_{3} \mathrm{H}<p$ $\mathrm{TsOH}<\mathrm{PhSO}_{3} \mathrm{H}$. By the way, $2.0 \times 10^{-3} \mathrm{~mol} \mathrm{dm}{ }^{-3} \mathrm{HNO}_{3}$ (prepared from aqueous $70 \% \mathrm{HNO}_{3}$ ) gave a large maxi-

$$
\begin{array}{ll}
\mathrm{RSO}_{3} \mathrm{H} \cdots & \mathrm{Q} \\
\mathrm{RSO}_{3} \mathrm{H} \cdots \mathrm{O}^{\circ} & \mathrm{O}
\end{array}
$$

Scheme 1 Homoconjugated species, $\mathrm{A}^{-}(\mathrm{HA})_{2}$, from a sulfonic acid. 


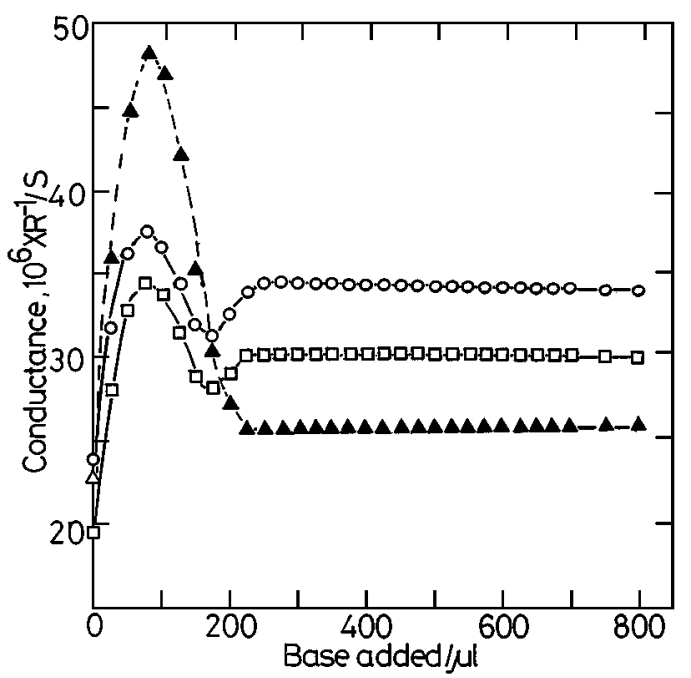

Fig. 2 Conductometric titration curves of $0.0050 \mathrm{~mol} \mathrm{dm}^{-3}$ sulfonic acids $(25 \mathrm{ml})$ with $0.50 \mathrm{~mol} \mathrm{dm}^{-3}$ triethylamine in benzonitrile at $25^{\circ} \mathrm{C}$ : ( 4 ) methanesulfonic, ( $\left.\square\right) p$-toluenesulfonic, $(\mathrm{O})$ benzenesulfonic acid.

mum around the half-equivalence point, suggesting a strong homoconjugation reaction: $\mathrm{B}+2 \mathrm{HNO}_{3}$ $=\mathrm{BH}^{+}+\mathrm{NO}_{3} \cdot \mathrm{HNO}_{3}$. The homoconjugation constant of $\mathrm{NO}_{3}^{-} \cdot \mathrm{HNO}_{3}$ has been determined in acetone ${ }^{9}$ and acetonitrile. ${ }^{20}$ Verstegen has reported the dimerization constants for nitric acid in benzene, $o$-dichlorobenzene, and chloroform by distribution measurements. ${ }^{21}$

A stronger acid, trifluoromethanesulfonic acid $\left(\mathrm{CF}_{3} \mathrm{SO}_{3} \mathrm{H}\right)$, was also examined in benzonitrile. The conductances of $2.0 \times 10^{-3} \mathrm{~mol} \mathrm{dm}^{-3} \mathrm{CF}_{3} \mathrm{SO}_{3} \mathrm{H}$ increased linearly up to the equivalence point. However, for the higher concentration of $\mathrm{CF}_{3} \mathrm{SO}_{3} \mathrm{H}$, the slope of the increasing conductances changed around the halfequivalence point. Titrations of $5.0 \times 10^{-3} \mathrm{~mol} \mathrm{dm}^{-3}$ $\mathrm{CF}_{3} \mathrm{SO}_{3} \mathrm{H}$ with other bases (tributylamine, dibutylamine, pyridine, $\gamma$-picoline, $\gamma$-collidine, and $N, N$ dimethylaniline) gave similar changes of the conductances in the intermediate to the equivalence point. The complexity (the changes of the slope) in the intermediate to the equivalence point may suggest some reactions of species in the solution. It was found that trifluoromethanesulfonic acid (HA) formed the dimer $\left(\mathrm{H}_{2} \mathrm{~A}_{2}\right)$ in benzonitrile (vide infra). The dimer as well as the monomer of the acid can be neutralized by an amine base, as follows: $\mathrm{B}+\mathrm{H}_{2} \mathrm{~A}_{2} \rightleftharpoons \mathrm{BH}^{+} \ldots \mathrm{HA}_{2}^{-}$.

On the other hand, the neutralization point was distinctly observed by the intersection of linear conductance changes in the conductometric titration of perchloric acid $\left(\left[\mathrm{HClO}_{4}\right], \geq 2.0 \times 10^{-3} \mathrm{~mol} \mathrm{dm}^{-3}\right)$. The changes in conductance were rather slight; for instance, the conductance values for $5.0 \times 10^{-3} \mathrm{~mol} \mathrm{dm}^{-3} \mathrm{HClO}_{4}$ were 28.6, 29.7, 30.6, 30.3, and $30.0 \times 10^{-5} \mathrm{~S}$ (in the cell) at $0,0.5,1.0,2.0$, and 3.0 in the equivalence unit, respectively. According to our study, the acidity of $\mathrm{HClO}_{4}$ seemed to be definitely larger than that of $\mathrm{CF}_{3} \mathrm{SO}_{3} \mathrm{H}$ in benzonitrile, although the opposite order in

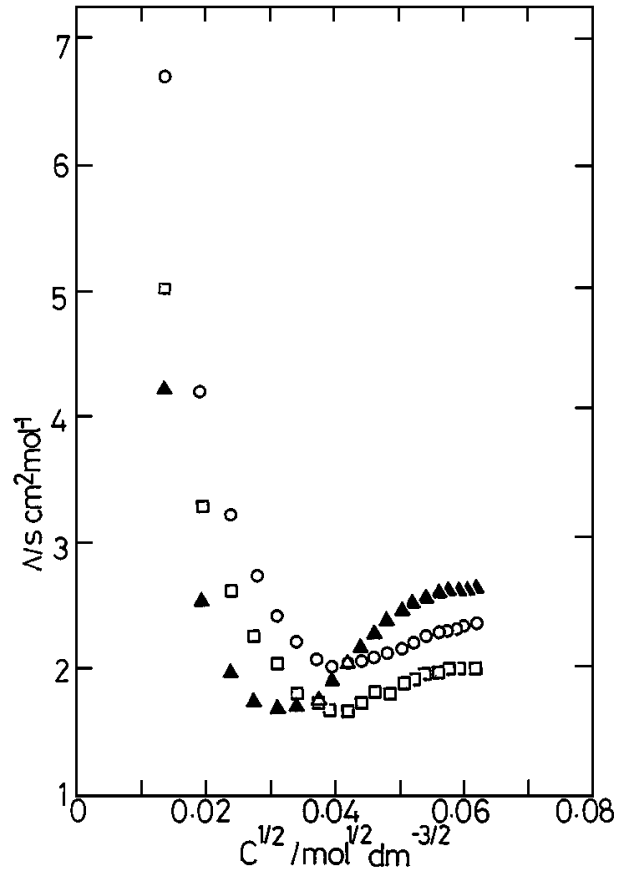

Fig. 3 Observed $\Lambda-C^{1 / 2}$ curves of sulfonic acids in benzonitrile at $25^{\circ} \mathrm{C}$ : ( $\Delta$ ) methanesulfonic, ( $\left.\square\right) p$-toluenesulfonic, ( $\left.\mathrm{O}\right)$ benzenesulfonic acid.

acetic acid ${ }^{22}$ or sulfuric acid ${ }^{23}$ has been suggested.

Kolthoff and Chantooni ${ }^{2}$ observed a distinct maximum around the two-third equivalence point in the conductometric titration curve of $\mathrm{H}_{2} \mathrm{SO}_{4}$ with butylamine in acetonitrile. They explained the phenomenon by the formation of $1: 1$ homoconjugation $\left(\mathrm{HSO}_{4}^{-} \cdot \mathrm{H}_{2} \mathrm{SO}_{4}\right)$ with insufficient fitting to the observed conductances. We think that the maximum at the $2 / 3$ and not the $1 / 2$ equivalence point should be attributed to the reaction of two conjugate anions and an acid molecule, i.e., $\left(\mathrm{HSO}_{4}^{-}\right)_{2} \mathrm{H}_{2} \mathrm{SO}_{4}$, as shown in Scheme 2. Two hydrogen bonds can operate between $\mathrm{HSO}_{4}{ }^{-}$and $\mathrm{H}_{2} \mathrm{SO}_{4}$, since the conjugate anion still possesses an $\mathrm{OH}$-group. Contrastingly, the conjugate anion from a sulfonic acid does not have $\mathrm{OH}$-group any more; therefore, the interaction (by a single bonding) between $\mathrm{RSO}_{3}{ }^{-}$and $\mathrm{RSO}_{3} \mathrm{H}$ ( $c f$. Scheme 1) must be too weak to operate in acetonitrile, and the interaction (or the maximum) can be distinctly observed only in the less solvating solvent, benzonitrile.

In order to investigate the association of the sulfonic acids in benzonitrile, the conductivities of the acids, themselves, were measured at $25^{\circ} \mathrm{C}$. Figure 3 shows the molar conductivities $\left(\Lambda / \mathrm{S} \mathrm{cm}^{2} \mathrm{~mol}^{-1}\right)$ of $p$-toluenesulfonic, benzenesulfonic, and methanesulfonic acids

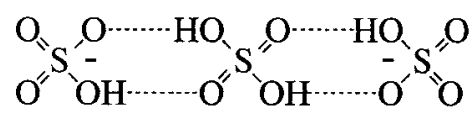

Scheme 2 The proposed homoconjugated species, $\left(\mathrm{HSO}_{4}^{-}\right)_{2} \mathrm{H}_{2} \mathrm{SO}_{4}$ 
over the concentration range of $(0.2-3.8) \times 10^{-3} \mathrm{~mol}$ $\mathrm{dm}^{-3}$. The $\Lambda$ values of $\mathrm{CH}_{3} \mathrm{SO}_{3} \mathrm{H}$ gave a minimum at

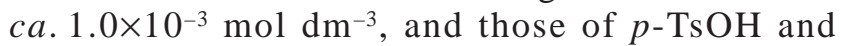
$\mathrm{PhSO}_{3} \mathrm{H}$ gave minima at ca. $1.6 \times 10^{-3} \mathrm{~mol} \mathrm{dm} \mathrm{dm}^{-3}$. The direct Shedlovsky analyses ${ }^{25}$ for the lower concentration points of the three acids were all not successful, and gave "negative" $\Lambda_{0}$ values. In MIBK (4-methyl-2pentanone: $\varepsilon_{\mathrm{r}} \approx 13$ ), a minimum in the $\Lambda-C^{1 / 2}$ curve of methanesulfonic acid has been reported by Fujinaga and Sakamoto. ${ }^{12}$ The complexities in the $\Lambda-C^{1 / 2}$ curves suggested the presence of a variety of species, such as "triple ions" and other higher ion aggregates. On the other hand, trifluoromethanesulfonic acid in benzonitrile gave a monotonical $\Lambda-C^{1 / 2}$ curve. Nevertheless, the direct Shedlovsky analysis of conductivities of $\mathrm{CF}_{3} \mathrm{SO}_{3} \mathrm{H}\left[\mathrm{C}=(0.4-7.7) \times 10^{-3} \mathrm{~mol} \mathrm{dm}^{-3}, 20\right.$ points $]$ gave an extremely large $\Lambda_{0}$ value (189.3) and a $K_{\mathrm{a}}$ value of $3.7 \times 10^{4}$, while the first 5 (lower concentration) points gave much smaller values, $\Lambda_{0}$ of 62.6 and $K_{\text {a }}$ of $2.8 \times 10^{3}$. Similar curious phenomena have been already reported: $c f$. Refs. 4,18 and 26 . The first 10 points gave an intermediate value between the values obtained from the 5 and 20 points. The intrinsic $\Lambda_{0}$ value could be obtained to be 64.2 by Kohlrausch's additivity law $\left(\Lambda_{0}\left(\mathrm{CF}_{3} \mathrm{SO}_{3} \mathrm{H}\right)=\Lambda_{0}\left(\mathrm{Et}_{4} \mathrm{NCF}_{3} \mathrm{SO}_{3}\right)+\Lambda_{0}\left(\mathrm{HClO}_{4}\right)-\Lambda_{0}\left(\mathrm{Et}_{4} \mathrm{~N}-\right.\right.$ $\left.\mathrm{ClO}_{4}\right)$ ). The whole $\Lambda$ value of $\mathrm{CF}_{3} \mathrm{SO}_{3} \mathrm{H}$ was roughly explained by both the $1: 1$ association $\left(\mathrm{H}^{+}+\mathrm{A}^{-} \rightleftharpoons \mathrm{HA}\right.$, $K_{1}=3 \times 10^{3}$ ) and $2: 2$ association $\left(2 \mathrm{HA} \rightleftharpoons \mathrm{H}_{2} \mathrm{~A}_{2}\right.$, $K_{41}=30$ ), after the procedure shown in ref. 4 . In this connection, an IR spectrum of pure $\mathrm{CF}_{3} \mathrm{SO}_{3} \mathrm{H}$ has suggested the dimer formation of $\mathrm{CF}_{3} \mathrm{SO}_{3} \mathrm{H} .{ }^{27}$ We have determined, by means of conductometry, the dimer formation constants of not only acids in $\mathrm{DMF}^{4}$, but also salts, $\mathrm{CF}_{3} \mathrm{COOLi}$ in propylene carbonate ${ }^{18}$ and sodium diphenyl phosphate $\left(\mathrm{Na}^{+}(\mathrm{PhO})_{2} \mathrm{PO}_{2}{ }^{-}\right)$in acetone. ${ }^{26}$

\section{References}

1. P. J. R. Bryant and A. W. H. Wardrop, J. Chem. Soc., 895 (1957).

2. I. M. Kolthoff and M. K. Chantooni, Jr., J. Am. Chem. Soc., 85, 426 (1963).

3. I. M. Kolthoff, Anal. Chem., 46, 1992 (1974).

4. M. Hojo, H. Hasegawa and Z. Chen, Bull. Chem. Soc. Jpn., 69, 2215 (1996).
5. T. Gunduz, E. Kilic, G. Ozkan, M. F. Awaad and M. Tastekin, Can. J. Chem., 68, 674 (1990).

6. M. Hojo and Y. Imai, Bull. Chem. Soc. Jpn., 56, 1963 (1983).

7. I. M. Kolthoff, M. K. Chantooni, Jr. and S. Bhowmik, J. Am. Chem. Soc., 88, 5430 (1966).

8. I. M. Kolthoff and M. K. Chantooni, Jr., J. Phys. Chem., 66, 1675 (1962).

9. Z. Pawlak, T. Jasinski and C. Dobrogowska, Roczniki Chem., 48, 1609 (1974).

10. K. Izutsu, "Acid-Base Dissociation Constants in Dipolar Aprotic Solvents", IUPAC Chemical Data Series No. 35, Blackwell, Oxford, 1990.

11. "CRC Handbook of Chemistry and Physics", 70th ed., D163, CRC Press, Boca Raton, 1989.

12. T. Fujinaga and I. Sakamoto, J. Electroanal. Chem., 85, 185 (1977).

13. K. Izutsu, I. M. Kolthoff, T. Fujinaga, M. Hattori and M. K. Chantooni, Jr., Anal. Chem., 49, 503 (1977).

14. M. Hojo, H. Hasegawa, Y. Miyauchi, H. Moriyama, H. Yoneda and S. Arisawa, Electrochim. Acta, 39, 629 (1994).

15. J. F. Coetzee and D. K. McGuire, J. Phys. Chem., 67, 1810 (1963).

16. V. Gutmann, "The Donor-Acceptor Approach to Molecular Interactions," Chap. 2, Plenum, New York, 1978.

17. M. Hojo, Y. Miyauchi and Y. Imai, Bull. Chem. Soc. Jpn., 63, 3288 (1990).

18. Y. Miyauchi, M. Hojo, H. Moriyama and Y. Imai, J. Chem. Soc., Faraday Trans., 88, 3175 (1992).

19. W. S. Muney and J. F. Coetzee, J. Phys. Chem., 66, 89 (1962).

20. I. M. Kolthoff, S. Bruckenstein and M. K. Chantooni, Jr., J. Am. Chem. Soc., 83, 3927 (1961).

21. J. M. P. J. Verstegen, J. Inorg. Nucl. Chem., 26, 1085 (1964).

22. A. Engelbrecht and B. M. Rode, Monatsh. Chem., 103, 1315 (1972).

23. D. G. Russell and J. B. Senior, Can. J. Chem., 52, 2975 (1974).

24. J. F. Coetzee, G. R. Padmanabhan and G. P. Cunningham, Talanta, 11, 93 (1964).

25. T. Shedlovsky, J. Franklin Inst., 225, 739 (1938).

26. M. Hojo, H. Hasegawa and Y. Morimoto, Anal. Sci., 12, 521 (1996).

27. R. Buzzoni, S. Bordiga, G. Ricchiardi, G. Spoto and A. Zecchina, J. Phys. Chem., 99, 11937 (1995).

(Received October 28, 1998)

(Accepted January 22, 1999) 